\title{
THE ORGANIZATION AND WORK OF THE FEDERAL RESERVE BOARD
}

\author{
By E. M. Patrerson, Ph.D. \\ Wharton School of Finance and Commerce, University of Pennsylvania.
}

Appreciation of the importance of the Federal Reserve Board is largely dependent upon an understanding of the conditions that called it into existence. Many of these facts are quite familiar, but a brief summary will not be amiss.

Banks in the United States may be classified in many ways, but the most suggestive in this connection is their grouping as national banks, state banks, trust companies, savings banks and private banks. On June 30, 1914, there were 26,765 of these different kinds of institutions. National banks which receive their charters from the federal government numbered 7,525. There were 14,512 state banks, 1,564 trust companies and 2,100 mutual and stock savings banks, all of which are chartered by the states or are organized under state laws. Finally there were 1,064 private banks unincorporated and only to a slight degree subject to any supervision.

The work performed by these institutions is of many different kinds although all of it may be termed financial. National banks exist chiefly to do commercial banking, i.e., to accept the deposits of business men and to make loans to others who are engaged in strictly commercial lines. Most of their deposits are payable on demand and accordingly their assets should be very liquid. State banks also are primarily commercial banks. Savings banks are of a ver $y$ different ty pe. Claims against them not being payable on demand, their assets may safely be invested in long time securities which are not so readily liquidated as the assets of commercial banks, but which do not involve any considerable element of risk. Trust companies, per se, perform financial business as trustees for others who lack the ability or the desire to act for themselves. Private banks may and do perform many different kinds of business but in the United States they have largely specialized in investment banking, i.e., the purchase and sale of securities. 
In practice these broad lines of distinctions are frequently ignored. Savings banks are quite closely restrained by the laws under which they operate and trust funds handled by trust companies must be invested in accordance with carefully worded legal requirements. On the other hand, both national and state banks, though primarily commercial, are also interested in other lines. Savings accounts are held by many of them and a considerable number have bond departments which buy government, municipal and ordinary corporate bonds for resale to the public. Private banks frequently do many different kinds of business under a single management and the work of many trust companies is of so varied a nature that they have often been referred to as "financial department stores."

This lack of differentiation of functions is a serious weakness and has frequently been a contributing, though not the sole cause, of disaster. In addition our lack of an elastic circulating medium, of a discount market and of a suitable fiscal agent for the federal government have been a combination of defects that seriously hampered us in normal times and in periods of strain have resulted in a complete collapse.

Among the remedies proposed a central bank was most often mentioned. Distrust of such an institution was, however, very strong. Unreasoning and unreasonable in many cases, although more carefully considered in others, opposition to it was intense enough to prevent its adoption. The Aldrich Bill was doomed to defeat from the outset. Consequently in 1913 a Democratic Congress faced an awkward problem. The country was ready for banking reform but, on the whole, opposed to a single central institution. Also the Democrats were influenced by their Jacksonian traditions, by their historical opposition to concentration of power and by their specific declaration against the Aldrich plan in their Baltimore platform of 1912. There is no occasion here to argue whether these considerations or others bearing more directly on the merits of the two possible methods of reform had the greater influence in the final decision. The choice was for a regional system rather than a central bank.

Having made such a choice the creation of a supervisory authority was of course a necessity. The Bank of England and the other central institutions of Europe have their boards of directors. 
Our new system, however, was to have from eight to twelve banks, each largely independent of the others. Each of the twelve that were finally established has its own board of nine directors and its own executive staff. Its problems and interests are largely confined to its own district. Its stock is owned by its member banks and it is certain to be influenced to a considerable degree by their preferences. Evidently some supervising and coördinating influence was needed. First of all it was necessary to recognize that the community has come to view the business of banking as quasipublic in its nature. Bank directors and officials are considered responsible to the general public as well as to the stockholders for the manner in which they conduct their business. Interests of depositors who are the bank's creditors are as important as those of the owners of the stock. The power exercised by a bank over the welfare of a community is often enormous and the disastrous effect of its failure is so serious that every possible precaution should be taken. Banking is not yet viewed in the United States as a proper field for government ownership and probably never will be, but the need for governmental regulation and control is clear.

Another reason for the creation of a supervisory body lies in our failure in the past to distinguish carefully between different kinds of banking. To this weakness reference was made at the beginning of this article. The Federal Reserve Act applies primarily to commercial banking as distinct from rural credits, investment banking and the business of the savings banks and trust companies. Here and there in the law exceptions to this general proposition may be found but they are for the most part concessions to a situation that can be remedied only a little at a time.

Commercial banks should have liquid assets but unfortunately our national and state banks have not always observed this rule. Advances to speculators and in aid of permanent investments are in the one case unsafe and in the other not easily repaid. In neither case are they liquid. Collateral offered as security is frequently unsaleable and actual purchases of stocks or bonds are often still more unsatisfactory. Even the so-called commercial paper bought in large quantities through note brokers has often been either speculative or investment in its nature instead of truly "commercial," and hence self-liquidating in its own life-time. 
The Federal Reserve Act set up new standards for commercial banking but such standards can not be automatically introduced. Some directing influence was needed to enforce the new law, and to define and apply its principles. A sympathetic appreciation of the existing situation with a clear perception of the goal to be attained were necessary. For this purpose a central authority was essential.

A third phase of the problem was the need in the United States of more coöperation. We have had no centralization of responsibility in our financial operations. Twelve reserve banks would clearly be better for this work than nearly 27,000 separate institutions but still more coördination of effort was desirable. More economical collection of checks, systematic effort to develop financial machinery for handling our foreign trade and better control over the importation and exportation of gold are illustrations of this third problem.

To these three reasons for the creation of the Federal Reserve Board perhaps others could be added but they are sufficient to make clear the need for such a body. To most if not all readers of this article, the leading facts regarding the Board are well known. It has seven members, of whom the Secretary of the Treasury and the Comptroller of the Currency, serve ex officio while the other five are appointed by the President of the United States. Their powers and duties are numerous but may be divided into six groups: First, the task of organizing the system by districting the country, establishing the reserve banks, and prescribing rules and regulations for the conduct of their business; second, continuous supervision of rediscounting operations by defining eligible paper, approving of rediscount rates and in other ways; third, control over the retirement of national banks notes as provided for in the law and over the issue of reserve bank bond-secured notes and federal reserve notes; fourth, general supervisory direction of the twelve reserve banks through the appointment of one third of the directors and in other ways; fifth, control of different kinds over the member banks; sixth, a large group of miscellaneous powers and duties.

Coöperating with the Board are several influences of importance. One is the Federal Advisory Council composed of one representative of each reserve bank, selected annually by its board of directors. Its powers are "(1) to confer directly with the 
Federal Reserve Board on general business conditions; (2) to make oral or written representations concerning matters within the jurisdiction of said board; (3) to call for information and to make recommendations in regard to discount rates, rediscount business, note issues, reserve conditions in the various districts, the purchase and sale of gold or securities by reserve banks, open-market operations by said banks, and the general affairs of the reserve banking system." Thus far the activities of the Council have not been of the sort to attract general notice, the most interesting to the public being a recent recommendation that the office of the Comptroller of the Currency be abolished. The real value of the Council as an advisory body is yet to be demonstrated.

Assistance also is rendered the Federal Reserve Board by the officials of the twelve Federal reserve banks. Three of the nine members of each board of directors are appointed by the Reserve Board and hence somewhat directly represent that body and the interests of the general public. One of these three is known as the federal reserve agent and acts as chairman of the local board of directors. To him especially the Peserve Board will look for advice and assistance but in practice there has apparently been and doubtless will continue to be complete harmony between that body and all of the directors and officials of the different reserve banks.

While the duties of the Reserve Board are onerous and their powers broad they are subject to several important restraints. First in order is the provision in the law that they may be removed from office for cause by the President of the United States. Second and more important is the general publicity surrounding all their work. Members of the Board occupy positions of importance and influence. Membership is an honor and violation of public confidence through dishonesty or incompetence would be a disgrace. In practice there is so little opportunity for concealment that we may expect the same ability and integrity that we assume in the Interstate Commerce Commission and the Supreme Court of the United States.

A third limitation on the board is to be found in its relations with the Treasury Department. In the Federal Reserve Act is the following statement explanatory of the spheres of authority of the Secretary of the Treasury and of the board: 
Nothing in this act contained shall be construed as taking away any powers heretofore vested by law in the Secretary of the Treasury which relates to the supervision, management and control of the Treasury Department and bureaus under such department, and wherever any power vested by this act in the Federal Reserve Board or the federal reserve agent appears to conflict with the powers of the Secretary of the Treasury, such powers shall be exercised subject to the supervision and control of the Secretary.

This statement in the law still left several questions undecided and the Attorney General of the United States was asked to render an "opinion (a) whether accounts of moneys derived from the semi-annual assessment to be levied on federal reserve banks by the Federal Reserve Board are subject to audit by one of the auditors of the Treasury Department, and (b) as to the status of the Federal Reserve Board, particularly with reference to the Treasury Department."

In reply to the first of these inquiries the Attorney General gave it as his opinion that the moneys mentioned are "public moneys" within the meaning of the statutes of the United States and consequently subject to audit by one of the auditors of the Treasury Department.

On the second point his opinion was equally definite. Although the Secretary of the Treasury is chairman of the board he is specifically subjected to the directions of the board except, as recited above, where there is opportunity for dispute over jurisdiction. The opinion on this point was worded thus:

It is evident that, while the purpose of this clause was, amongst other things, to insure the preservation and supremacy of all existing powers of the Secretary of the Treasury in all cases where it might be claimed that such powers overlapped, or conflicted with those of the Federal Reserve Board, nevertheless by this very provision the act clearly recognized the existence of powers of the Board independent of the Secretary in cases where no such conflict existed.

This ruling is merely an official recognition of a point about which there could in any case have been very little doubt. It makes clear that the status of the board is one independent of the Treasury Department but, of course, does not modify the power of the Secretary of the Treasury on points where his duties are specifically defined either in the Federal Reserve Act or in other statutes.

These powers are large and some of them are especially important in their relation to the work of the Reserve Board. The 
Secretary's position as chairman of the Board and his supervision of the work of the Comptroller of the Currency, his subordinate in the Treasury Department, who is also a member of the Board, give him considerable influence over at least one vote besides his own. His power to determine, within limits, the use of certain receipts in the form of franchise taxes imposed on the reserve banks and to use his discretion regarding the distribution of the general fund of the Treasury between the member banks, the reserve banks and the Treasury itself are further illustrations of the importance of his position.

Subject then to the limitations named the Federal Reserve Board is an independent body, not merely supervisory but also distinctly administrative with extensive powers. A brief survey of its form of organizaton indicates its own conception of its functions. In its annual report for the year 1914 there is reported as employed by the Board, 45 persons in addition to a counsel, a secretary and an assistant secretary with a total pay roll, including salaries of the members, amounting to $\$ 147,900$.

The work was organized by establishing three divisions, the first entitled "Correspondence Division," the second "Division of Audit and Examination" and the third "Division of Reports and Statistics." The duties of the first and third of these divisions are clearly indicated by their names. The nature of the work performed by the second, that of audit and examination is made more evident by an examination of its six functions which are: (1) examination and audit of federal reserve banks and of the books and accounts of federal reserve agents; (2) special examinations of member banks or of banks applying for membership; (3) special investigations as, for example, of applications for the establishment of domestic or foreign branches or of member banks for permission to exercise trust company powers; (4) oversight of the development of a system of credit bureaus, including one at each of the federal reserve banks and a central bureau at Washington; (5) analysis of reports and statements, a work in which this division coöperates with the Division of Reports and Statistics; and (6) audit of bills incurred by the Federal Reserve Board.

The problems facing the board at the time of its organization were numerous and perplexing. Complex and serious as they would have been under any circumstances, their difficulty was 
immeasurably increased by the outbreak of the European War. Several of the most important are discussed in the following articles in this section of The Annals. The work and duties of the Board and of the twelve reserve banks as also those of the many member banks are so interdependent that discussion of them in many instances is an analysis of the operation of the entire reserve system.

Yet the Reserve Board as a supervisory and administrative body ranks with the Interstate Commerce Commission and the more recently organized Federal Trade Commission in its importance. Matters of banking detail are very properly left to the member banks and the twelve reserve banks as technical details of transportation are left in the hands of the railroads. But formulation of banking standards, shaping of general policies, application of well recognized banking principles, coördination of effort, the work of supervising and controlling our banking machinery are placed in the hands of the board.

Most important of all, the interests of the general public are entrusted to the board. Immersed in his daily routine and constantly under pressure to earn dividends that will satisfy stockholders, bank officials may easily become oblivious to the welfare of the community. Careless lending of funds, high interest rates and heavy charges for the collection of checks and drafts place a burden upon the public from which it can and should be relieved whenever such relief is possible.

However we may easily fall into the error suggested by $\mathrm{Mr}$. Seay in a later article. Perhaps the emphasis should be placed not on the regulative aspects of the new system, but on the fact that under it we shall have a better organization of the banking resources of the country. In so far as regulation may be needed we certainly should welcome it but the second result is fully as important.

In concluding this outline of the organization and functions of the Reserve Board we can do no better than to repeat in a condensed form the results attained during the first year of the operation of the reserve system as recently stated by Mr. H. P. Willis, the Secretary of the board.

First-A long step has been taken toward securing the standardization of commercial paper and toward making the assets of member banks more liquid. 
Second-Through the careful use of the power to grant trustee and executor powers a premium has been placed upon sound banking.

Third-Many banks in need of assistance have been directly aided through the rediscount policy.

Fourth-There has been developed the beginning of a system of bankers' acceptances.

Fifth-An improved system of clearings and collections has been inaugurated.

Sixth-In general there has been a tremendous increase in recognition of sound principles of banking and credit. 